\title{
OPTIMALAUS PASAULIO EKSPORTO PASKIRSTYMO MODELIAVIMAS
}

\section{Viktorija Tauraitè}

Vytauto Didžiojo universitetas, Kaunas, Lietuva

\section{ANOTACIJA}

Straipsnyje siekiama identifikuoti optimalų pasaulio eksporto paskirstymą tarp 11 šalių, šalių grupių: ES 28, Rusijos, Kanados, Jungtinių Amerikos Valstijų, Meksikos, Brazilijos, Kinijos (išskyrus Honkongą), Japonijos, Pietų Korejos, Indijos, Singapūro trims atvejams, kai pageidaujamas bendras pasaulio eksportas yra: 1) minimalus; 2) vidutinis; 3) maksimalus. Atlikus tyrimą išsiaiškinta, kad trys dominuojančios šalys visais atvejais pasaulio eksporto apimties atžvilgiu sutampa: ES 28, Kinija ir JAV, o mažiausios eksporto apimtys tenka Indijai ir Brazilijai.

Raktažodžiai: tarptautinè prekyba, eksportas, matematinis modeliavimas.

\section{IVADAS}

Ekonominiu aspektu visuomenès gerovė valstybèje yra užtikrinama socialinių išlaidų nemažèjimo ir tinkamų sąlygų suformavimu išmokoms gauti (Guogis, 2006). Globaliame pasaulyje, kur ekonominiai, finansiniai, prekybiniai ir kiti santykiai tampa vis greitesni, neužtenka visuomenès gerovès užtikrinti socialinėmis garantijomis. Pasak A. Liučvaitienès, K. Peleckio (2011), gamintojams taip pat neužtenka užtikrinti tik geros produkcijos kokybės vartotojams. Gamintojams, verslininkams svarbūs verslo, prekybiniai santykiai su užsienio investuotojais ir efektyvių, optimalių tarptautinių santykių vykdymas tiek mikro- (įmonių), tiek makro- (šalių) lygmeniu. Taigi aktualu atlikti optimalaus pasaulio eksporto modeliavimą, atsižvelgiant i pageidaujamą bendrą pasaulio eksporto apimtị. Manytina, kad tai turètų teigiamos įtakos globalios pasaulio gerovès pokyčiams.

Taigi šio tyrimo objektas - pasaulio eksporto paskirstymas. Tyrimo problema: koks yra optimalus pasaulio eksporto paskirstymas tarp 11 pasaulio šalių, šalių grupių, kai pageidaujamas bendras pasaulio eksportas yra minimalus, vidutinis ar maksimalus.

Ankstesniuose moksliniuose tyrimuose pastebėta, kad yra tyrimų tarptautinès prekybos tematika (Burinskienè, 2014; Tauraite, 2017; Darshini, 2017 ir kt.). Kita vertus, nors matematinio modeliavimo metodas yra naudojamas moksliniuose tyrimuose (Stonkienè, 2013; Radziukynas, Nemura, 2007 ir kt.), nepavyko rasti tyrimo, kurio metu būtų naudojamas matematinis modeliavimas taikant tiesinio programavimo metodą ir identifikuojant optimalų eksporto paskirstymą, atsižvelgiant $\mathfrak{i}$ tam tikras sąlygas. Taigi, siekiant papildyti mokslinių tyrimų ịvairovę, yra atliekamas pasaulio eksporto paskirstymo matematinis modeliavimas atsižvelgiant i pageidaujamą bendrą pasaulio eksporto apimti.

Tyrimo tikslas - nustatyti optimalų pasaulio eksporto paskirstymą tarp 11 šalių ar šalių grupių (ES 28, Rusijos, Kanados, Jungtinių Amerikos Valstijų, Meksikos, Brazilijos, Kinijos (išskyrus Honkongą), Japonijos, Pietų Korejos, Indijos, Singapūro) trims skirtingiems atvejams, kai pageidaujamas bendras pasaulio eksportas yra: 1) minimalus; 2) vidutinis; 3) maksimalus.

\section{Tyrimo uždaviniai:}

1. Pristatyti tyrimo metodiką. 
2. Identifikuoti optimalų pasaulio eksporto paskirstymą tarp 11 pasaulio šalių, šalių grupių trims atvejams, atsižvelgiant ị pageidaujamą bendrą pasaulio eksporto dydị.

3. Apibendrinti optimalaus pasaulio eksporto paskirstymo rezultatus pateikiant rekomendacijas.

Tyrimas atliekamas taikant atvejo metodą (trys hipotetiniai atvejai), lyginamosios analizès metodą, o matematinio modeliavimo metu naudojamas tiesinio programavimo metodas. Atsižvelgiant ị naujausius statistinius duomenis, matematiniam modeliavimui taikomi 2011-2015 m. Eurostat statistiniai duomenys. Šis straipsnis yra tarsi tęsinys V. Tauraitès (2017) tyrimo, kuriuo buvo atliekama pasaulio eksporto dinaminè analizè ir prognozavimas, nustatytas skirtingas pasaulio eksporto pasiskirstymas tarp šalių 2002-2014 m. Kita vertus, šio tyrimo metu pasaulio eksporto analizė atliekama kitu aspektu: identifikuojamas optimalus pasaulio eksporto paskirstymas atsižvelgiant ị pageidaujamą pasaulio eksporto dydị.

\section{METODIKA}

Tyrimo logika. Pageidaujamai bendrai pasaulio eksporto (minimalaus, vidutinio, maksimalaus) apimčiai apskaičiuoti naudojami 2011-2015 m. Eurostat (2017) duomenys. Šis laikotarpis pasirinktas siekiant gauti santykiškai tiksliausius duomenis po pasaulinès finansų krizès. 2011-2015 m. laikotarpis identifikuotas remiantis ekonomisto Ž. Maurico (2015) skirstymu. Atsižvelgiant i prieinamus Eurostat duomenis (apie pasaulio eksporto apimtis), optimalus pasaulio eksporto paskirstymas atliekamas tarp 11 šalių, šalių grupių: ES 28, Rusijos, Kanados, Jungtinių Amerikos Valstijų (toliau - JAV), Meksikos, Brazilijos, Kinijos, Japonijos, Pietų Korejos, Indijos, Singapūro. Tyrimo metu analizuojama 11 šalių, o kitos pasaulio šalys, šalių grupès neanalizuojamos dèl duomenų trūkumo. Taigi ir į matematinị modelị nėra įtraukiamos likusios pasaulio šalys. Dèl šios priežasties nagrinèjamų šalių bendra eksporto dalis procentais nėra lygi 100\%.

Pirmas hipotetinis atvejis yra susijęs su minimalia pageidaujamo pasaulio eksporto verte, apskaičiuojama pagal 1 formulę:

$$
\min \left(\sum X_{2011} ; \sum X_{2012} ; \sum X_{2013} ; \sum X_{2014 ;} \sum X_{2015}\right)(1),
$$

kur: $\min$ - atitinkamos duomenų eilutés minimali reikšmė (procentais);

$X$ - atitinkamų metų pasaulio eksporto apimtis (procentais).

Kitaip sakant, pasaulio eksporto apimtis yra apskaičiuojama, kaip 11 šalių metinės eksporto apimties (procentais) suma.

Pirmo atvejo pasaulio eksporto optimalaus paskirstymo matematinis modelis pagal pageidaujamą minimalią pasaulio eksporto apimtị (žr. 2 formulę):

$$
x_{1}+x_{2}+x_{3}+x_{4}+x_{5}+x_{6}+x_{7}+x_{8}+x_{9}+x_{10}+x_{11}=X_{\min }(2) \text {, }
$$

kur $x$ yra šių šalių eksporto apimtys: $x_{1}-$ ES $28 ; x_{2}-$ Rusijos; $x_{3}-$ Kanados; $x_{4}-\mathrm{JAV} ; x_{5}-$ Meksikos; $x_{6}$-Brazilijos; $x_{7}-$ Kinijos; $x_{8}-$ Japonijos; $x_{9}-$ Pietų Korejos; $x_{10}$-Indijos; $x_{11}-$ Singapūro. Kintamieji $x_{1}, x_{2}, x_{3}, \ldots, x_{11}$ matuojami procentais;

$X_{\min }$ - 2011-2015 m. bendro pasaulio eksporto minimali reikšmė (procentais).

Eksporto paskirstymo bendrieji matematinio modelio apribojimai (tinkantys visiems trims hipotetiniams atvejams; žr. 3-15 formules nelygybes): 
$x_{1}, \quad x_{2}, x_{3}, \ldots, x_{11} \geq 0(3) ; x_{1}, x_{2}, x_{3}, \ldots, x_{11} \leq 100(4) ; 15,5 \leq x_{1} \leq 16,3(5) ; 2,7 \leq x_{2} \leq 3,8$ (6); $3,2 \leq x_{3} \leq 3,5$ (7); $10,9 \leq x_{4} \leq 13 ; 4$ (8); $2,6 \leq x_{5} \leq 3,0$ (9); $1,5 \leq x_{6} \leq 1,9$ (10); $14,0 \leq x_{7} \leq 17,8$ (11); $4,9 \leq x_{8} \leq 6,1(12) ; 3,9 \leq x_{9} \leq 4,1(13) ; 2,1 \leq x_{10} \leq 2,4$ (14); $2,7 \leq x_{11} \leq 3,0$ (15).

3-4 formulès nurodo, kad atitinkamos šalies eksporto apimtis turi būti ne neigiamas skaičius ir ne didesnis nei 100\%. 5-15 formulès apibrèžia atitinkamos šalies galimas eksporto apimties svyravimo ribas. Atitinkamos šalies mažiausios ir didžiausios eksporto apimties reikšmès apskaičiuotos remiantis pasaulio eksporto 2011-2015 m. Eurostat (2017) statistiniais duomenimis.

Antras hipotetinis atvejis yra susijęs su vidutine pageidaujamo pasaulio eksporto verte, apskaičiuojama pagal 16 formulę:

$$
\text { vid }\left(\sum X_{2011} ; \sum X_{2012} ; \sum X_{2013} ; \sum X_{2014 ;} \sum X_{2015}\right)(16)
$$

kur: vid - atitinkamos duomenų eilutès vidutinè reikšmė (procentais).

Antro atvejo pasaulio eksporto optimalaus paskirstymo matematinis modelis pagal pageidaujamą vidutinę pasaulio eksporto apimtị (žr. 17 formulę):

$$
x_{1}+x_{2}+x_{3}+x_{4}+x_{5}+x_{6}+x_{7}+x_{8}+x_{9}+x_{10}+x_{11}=X_{v i d}(17) \text {, }
$$

kur: $x_{1}, x_{2}, x_{3}, \ldots, x_{11}$ - atitinka pirmo atvejo matematinio modelio 11 skirtingu pasaulio šalių, šalių grupių žymėjimų paaiškinimus (žr. 1 formulès žymėjimų reikšmes); $X_{v i d}-2011-2015$ m. bendro pasaulio eksporto vidutinè reikšmė (procentais).

Trečias hipotetinis atvejis yra susijęs su maksimalia pageidaujamo pasaulio eksporto verte, apskaičiuojama pagal 18 formulę:

$$
\max \left(\sum X_{2011} ; \sum X_{2012} ; \sum X_{2013} ; \sum X_{2014} ; \sum X_{2015}\right)(18),
$$

kur: max - atitinkamos duomenų eilutès maksimali reikšmė (procentais).

Trečio atvejo pasaulio eksporto optimalaus paskirstymo matematinis modelis pagal pageidaujamą maksimalią pasaulio eksporto apimtị (žr. 19 formulę):

$$
x_{1}+x_{2}+x_{3}+x_{4}+x_{5}+x_{6}+x_{7}+x_{8}+x_{9}+x_{10}+x_{11}=X_{\max }(19) \text {, }
$$

kur: $x_{1}, x_{2}, x_{3}, \ldots, x_{11}$ - atitinka pirmo atvejo matematinio modelio 11 skirtingų pasaulio šalių, šalių grupių žymėjimų paaiškinimus (žr. 1 formulès žymèjimų reikšmes); $X_{\max }-2011-2015 \mathrm{~m}$. bendro pasaulio eksporto maksimali reikšmė (procentais).

Empiriniam tyrimui atlikti naudotasi Eurostat duomenų baze, o duomenys apdoroti naudojant Microsoft Excel matematinę skaičiuoklę bei Solver'io įrankį.

Atliekant empirinị tyrimą, laikomasi šių metodinių prielaidų:

1. Optimalus pasaulio eksporto apimties paskirstymas turi įtakos teigiamiems šalies / pasaulio gerovės pokyčiams.

2. Bendra pasaulio eksporto apimtis atitinka 11 šalių, šalių grupių (ES 28, Rusijos, Kanados, JAV, Meksikos, Brazilijos, Kinijos, Japonijos, Pietų Korejjos, Indijos, Singapūro) eksporto apimties (procentais) sumos duomenis.

3. Pageidaujamo pasaulio eksporto apimties (minimalios, vidutinès, maksimalios) dydis (procentais) atitinka 2011-2015 m. pasaulio eksporto duomenų eilutès minimalią, vidutinę, maksimalią (priklausomai nuo analizuojamo hipotetinio atvejo) reikšmę.

4. Kiekvienos ị matematinị modeli įtrauktos pasaulio šalies, šalių grupès (iš viso 11) eksporto apimtis (procentais) yra neneigiamas skaičius ir ne didesnis kaip 100\%. 
Kiekvienos ị matematinị modeli ittrauktos pasaulio šalies, šalių grupès (iš viso 11) eksporto galimos svyravimo ribos atitinka 2011-2015 m. esančią atitinkamos šalies mažiausią ir didžiausią eksporto apimties reikšmę.

Tyrimo turinys. Pirma, identifikuojamas optimalus pasaulio eksporto apimties paskirstymas tarp 11 šalių, kai pageidaujama minimali pasaulio eksporto apimtis. Antra, nustatomas optimalus pasaulio eksporto apimties paskirstymas tarp 11 šalių, kai pageidaujama vidutinè pasaulio eksporto apimtis. Trečia, identifikuojamas optimalus pasaulio eksporto apimties paskirstymas tarp 11 šalių, kai pageidaujama maksimali pasaulio eksporto apimtis. Ketvirta, atliekama palyginamoji analizè tarp trijų skirtingų atvejų.

Tyrimo metodų pagrindimas ir apibūdinimas. Optimalaus pasaulio eksporto paskirstymo modeliavimas atliekamas taikant tris metodus:

Atvejo analizé. Šis metodas taikomas siekiant identifikuoti optimalų pasaulio eksporto paskirstymą trims hipotetiniams atvejams, atsižvelgiant i pageidaujamą pasaulio eksporto dydį. H. L. Kee, H. Tang'as (2016), F. K. Suri ir A. Banerji (2016) ir kiti taip pat taiko atvejo analizès metodą.

Matematinis modeliavimas - šio tyrimo metu matematinis modeliavimas atliekamas naudojant tiesini programavimo metodą. Šis metodas yra taikomas siekiant nustatyti optimalų pasaulio eksporto paskirstymą tarp 11 šalių, šalių grupių, atsižvelgiant ì pageidaujamą pasaulio eksporto apimti. Optimalus pasaulio eksporto paskirstymas identifikuojamas naudojant Microsoft Excel programos įrankiu. Nors nebuvo rasta analogiško tyrimo, kurio metu būtų taikomas Solver'io matematinis modeliavimas optimaliam eksporto paskirstymui nustatyti, L. Stonkienė (2013) taiko matematinio modeliavimo metodą (biocheminių reakcijų srityje), o V. Radziukynas, A. Nemura (2007) - elektros energetikos sistemos su vèjo elektrinėmis srityje.

Lyginamoji analize $\dot{e}$ S Sis metodas naudojamas siekiant nustatyti pagrindinius skirtumus ir / ar panašumus tarp trijų analizuojamų atvejų. Moksliniuose tyrimuose, susijusiuose su eksportu palyginamają analizę taiko ir tokie mokslininkai kaip J. Čepinskis, E. Bendoraitienė (2012), I. Sergeev'as, T. Ponomarenko (2013) ir kiti.

Taigi šių trijų metodų taikymas siekiant nustatyti optimalų pasaulio eksporto paskirstymą papildo mokslinių tyrimų įvairovę, o ypač tyrimų metodus tarptautinès prekybos srityje.

Tyrimo ribotumai. Tyrimo kontekstas sudarytas iš 11 šaliu, šaliu grupių. ES 28 šalys ir „likęs pasaulis“ išsamiau nėra analizuojamas. Matematinio modelio bendrieji apribojimai, susiję su atitinkamos šalies eksporto svyravimo ribomis, paremti 2011-2015 m. duomenimis. Tai santykiškai trumpa duomenų eilutè, kuri gali lemti netinkamas interpretacijas ilguoju laikotarpiu. Kita vertus, šiuo tyrimu siekiama išvengti galimų statistinių duomenų netikslumų (juos gali lemti finansinè krizė ir pan.) ir analizei atlikti pasirenkami tik pokrizinio laikotarpio statistiniai duomenys.

Tyrimo privalumai. Sudarytas matematinis modelis yra: (1) santykiškai paprastas, suprantamas; (2) reikalaujantis santykiškai mažai laiko ir galimybių resursų; (3) gali būti tobulinamas, ị matematinị modeli įtraukiant papildomus kintamuosius, apribojimus. 


\section{TYRIMO REZULTATAI IR APTARIMAS}

Minimali pageidaujama pasaulio eksporto apimtis. Pritaikius tiesinio programavimo metodą, 1 paveiksle pateikiamas optimalus pasaulio eksporto paskirstymas tarp 11 šalių, šalių grupių, pageidaujant minimalios pasaulio eksporto apimties (šiuo atveju -67,4\%).

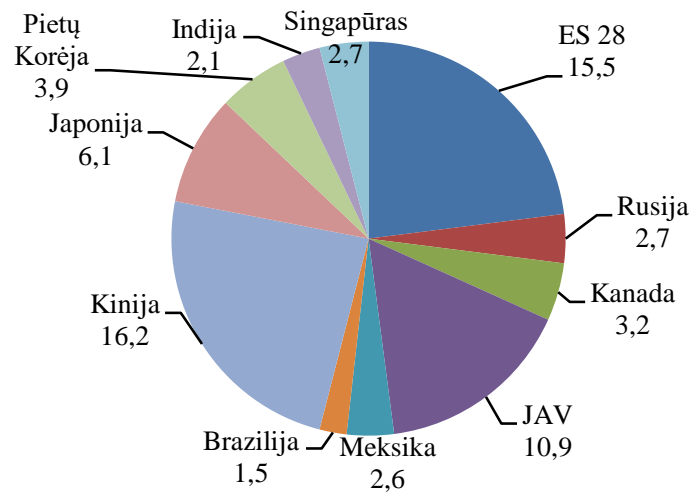

Pastaba. Šalies eksporto apimtis pateikiama procentais.

1 pav. Optimalaus pasaulio eksporto paskirstymas, kai pageidaujama minimali bendra pasaulio eksporto apimtis

Taigi didžiausios pasaulio eksportuotojos turètų būti Kinija (16,2\%), ES 28 (15,5\%) ir JAV (10,9\%), mažiausios - Brazilija (1,5\%), Indija (2,1\%) ir Meksika (2,6\%). Optimalus pasaulio eksporto paskirstymas tarp pasaulio šalių, kuris identifikuotas pageidaujant minimalios pasaulio eksporto apimties, yra panašus į 2012 m. pasaulio eksporto paskirstymą tarp šalių (žr. 1-2 pav.).

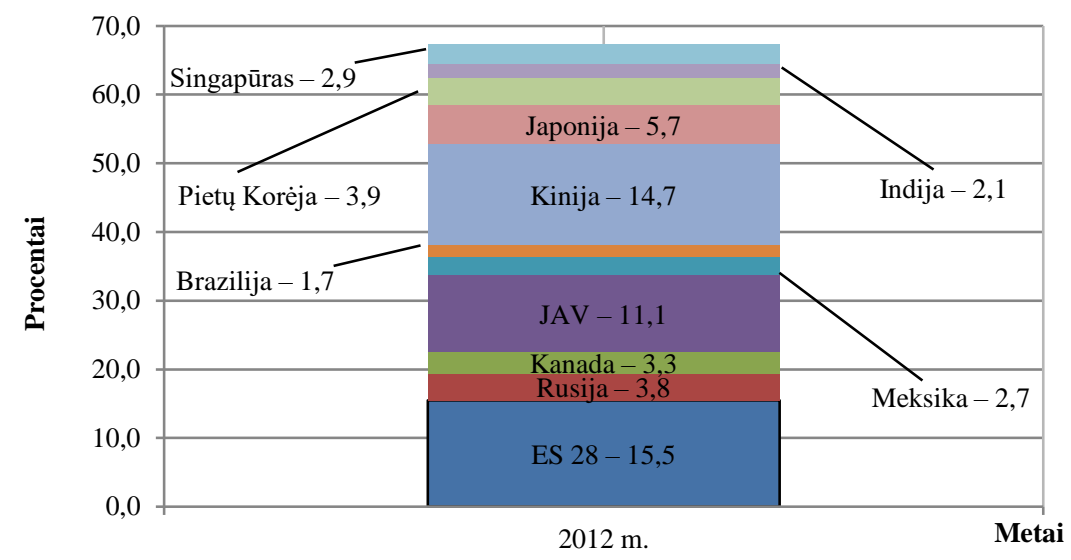

Pastaba. Paveikslas sudarytas autorès, remiantis Eurostat (2017) duomenimis. Eksportas pateikiamas procentais nuo bendros pasaulio eksporto apimties.

2 pav. Pasaulio eksporto pasiskirstymas pagal šalis 2012 m.

Ši išvada yra logiška, nes minimali pasaulio eksporto apimtis buvo nustatyta $2012 \mathrm{~m}$. (žr. 3 pav.). 


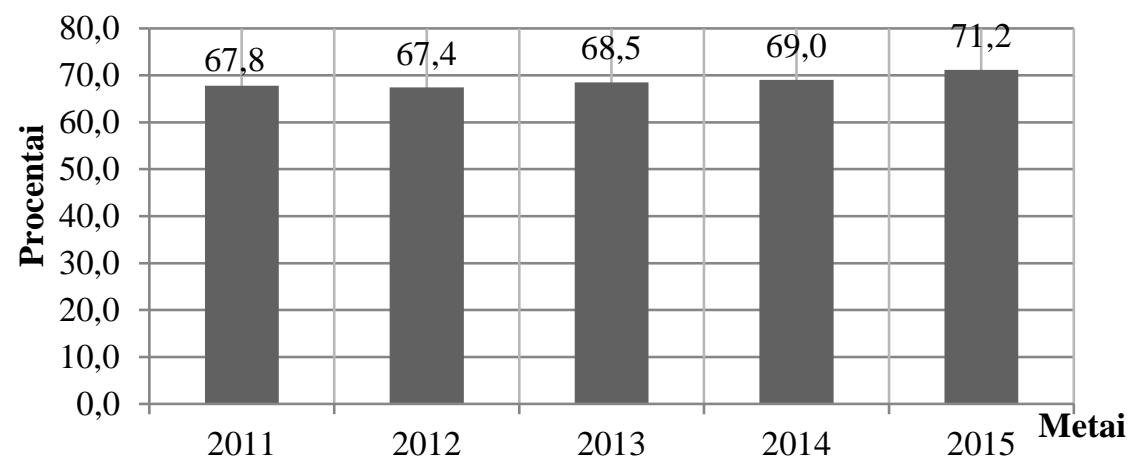

Pastaba. Paveikslas sudarytas autorès, remiantis Eurostat (2017) duomenimis. Eksportas pateikiamas procentais nuo bendros pasaulio eksporto apimties.

3 pav. Bendra pasaulio eksporto dinamika 2011-2015 m.

Kita vertus, nustatytas optimalaus pasaulio eksporto apimčių paskirstymas tarp šalių skiriasi nuo 0,1 iki 1,5 procentinių punktų (toliau - p. p.), lyginant su $2012 \mathrm{~m}$. statistiniais duomenimis (žr. 12 pav.). Kadangi skirtumas yra santykiškai nedidelis, galima teigti, kad 2012 m. pasaulio eksporto apimtys buvo santykiškai optimaliai paskirstytos laikantis modeliu suformuotų metodinių prielaidų ir bendrujų matematinio modelio apribojimų.

Vidutinė pageidaujama pasaulio eksporto apimtis. Optimalus pasaulio eksporto apimties paskirstymas tarp 11 šalių, šalių grupių, pageidaujant vidutinès pasaulio eksporto apimties (šiuo atveju-68,8\%), yra pateikiamas 4 paveiksle.

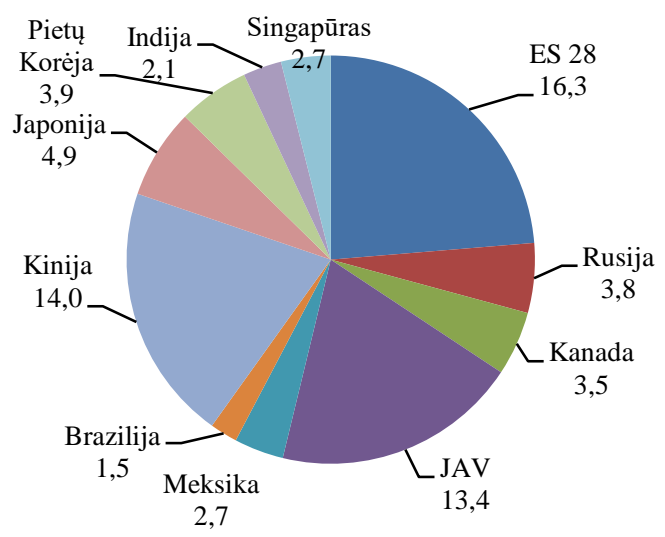

Pastaba. Šalies eksporto apimtis pateikiama procentais.

4 pav. Optimalaus pasaulio eksporto paskirstymas, kai pageidaujama vidutinė bendra pasaulio eksporto apimtis

Nustatyta, kad didžiausios pasaulio eksportuotojos turètų būti ES 28 (16,3\%), Kinija (14,0\%) ir JAV (13,4\%), mažiausios - Brazilija (1,5\%), Indija (2,1\%), Meksika (2,7\%) ir Singapūras (2,7\%). Optimalus pasaulio eksporto paskirstymas tarp pasaulio šalių pageidaujant vidutinès pasaulio eksporto apimties, yra panašus į 2013 m. pasaulio eksporto paskirstymą tarp šalių (žr. 4-5 pav.). 


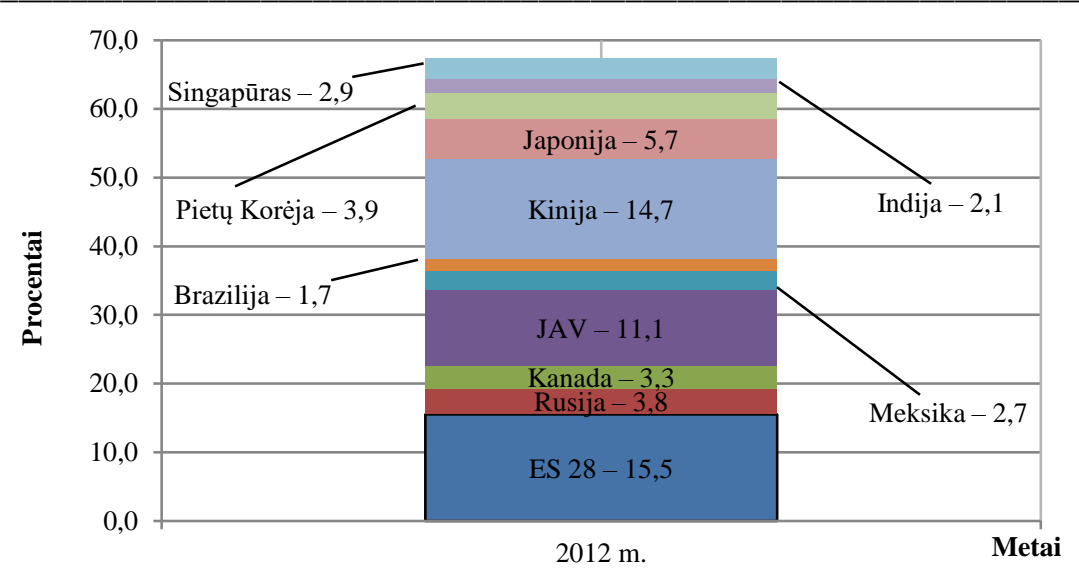

Pastaba. Paveikslas sudarytas autorès, remiantis Eurostat (2017) duomenimis. Eksportas pateikiamas procentais nuo bendros pasaulio eksporto apimties.

5 pav. Pasaulio eksporto pasiskirstymas pagal šalis 2013 m.

Vadinasi, 2011-2015 m. apskaičiuota vidutinè bendra pasaulio eksporto reikšmė $(68,8 \%)$ yra panaši i 2013 m. (68,5\%; žr. 3 pav.). Nustatytas optimalus pasaulio eksporto apimčiu paskirstymas tarp šalių skiriasi nuo 0,1 iki 2,3 p. p., lyginant su 2013 m. statistiniais duomenimis (žr. 4-5 pav.). Galima daryti išvadą, kad 2013 m. pasaulio eksporto apimtys buvo paskirstytos palyginti optimaliai, laikantis modeliu suformuotų metodinių prielaidų ir bendrųų matematinio modelio apribojimų.

Maksimali pageidaujama pasaulio eksporto apimtis. 6 paveiksle yra pateikiamas optimalus pasaulio eksporto apimties paskirstymas tarp 11 šalių, šalių grupių, pageidaujant maksimalios pasaulio eksporto apimties reikšmè (šiuo atveju - 71,2\%).

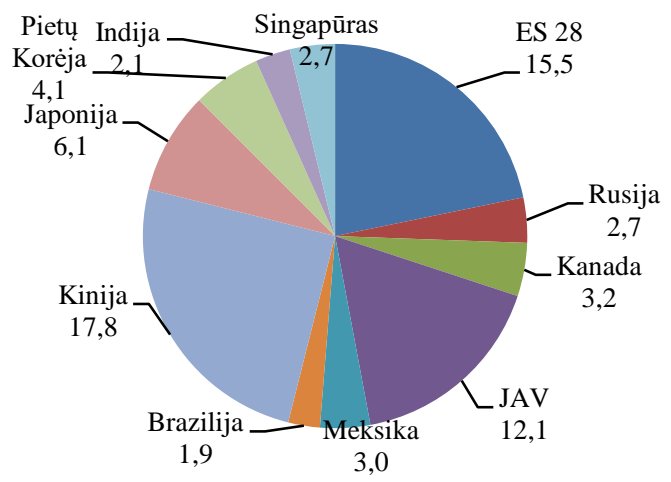

Pastaba. Šalies eksporto apimtis pateikiama procentais.

6 pav. Optimalaus pasaulio eksporto paskirstymas, kai pageidaujama vidutinė bendra pasaulio eksporto apimtis

Identifikuota, kad didžiausios pasaulio eksportuotojos turètų būti Kinija (17,8\%), ES 28 (15,5\%), JAV (12,1\%), mažiausios - Brazilija (1,9\%), Indija (2,1\%), Singapūras (2,7\%) ir Rusija (2,7\%). Pastebima, kad optimalus pasaulio eksporto paskirstymas tarp pasaulio šaliu pageidaujant maksimalios pasaulio eksporto apimties, yra panašus ị $2015 \mathrm{~m}$. pasaulio eksporto paskirstymą tarp šalių (žr. 6-7 pav.). 


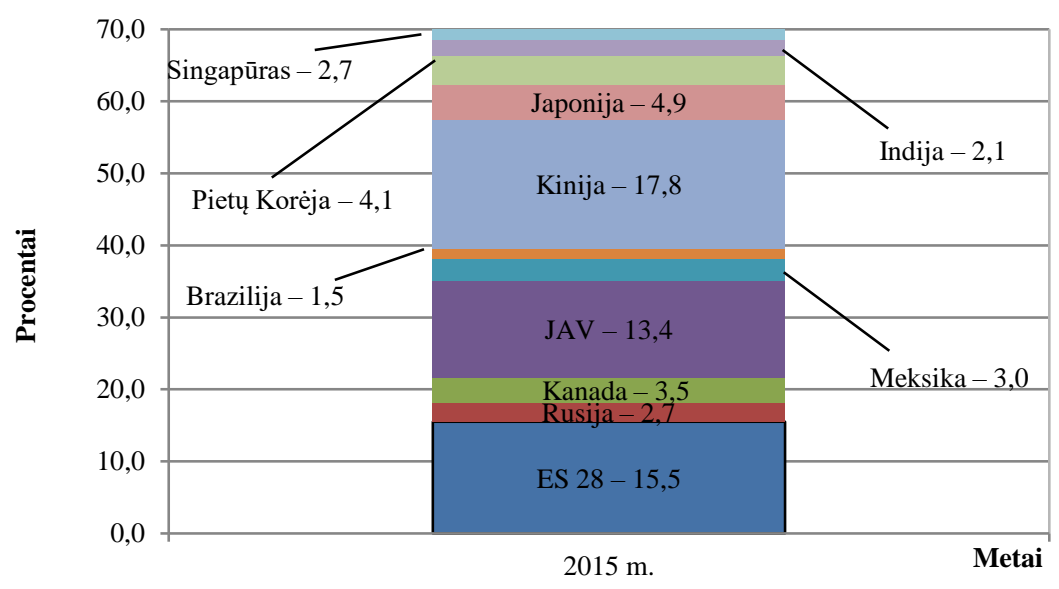

Pastaba. Paveikslas sudarytas autorès, remiantis Eurostat (2017) duomenimis. Eksportas pateikiamas procentais nuo bendros pasaulio eksporto apimties.

\section{7 pav. Pasaulio eksporto pasiskirstymas pagal šalis 2015 m.}

Tai logiška, nes 2011-2015 m. laikotarpiu maksimali pasaulio eksporto apimtis buvo nustatyta $2015 \mathrm{~m}$. (žr. 3 pav.). V. Tauraitè (2017), atlikdama $2015 \mathrm{~m}$. pasaulio eksporto prognozavimą, taip pat pažymėjo, kad $2015 \mathrm{~m}$. stipriausios pasaulio šalys eksporto aspektu atitinkamai turètų būti Kinija, ES ir JAV. Kita vertus, užsienio mokslininkai J. O'Neill'as ir kt. (2005), D. Wilson'as, R. Purushothaman'as (2003) akcentuoja JAV, Kinijos ir Japonijos potencialą 2025 m., o 2050 m., pasak tyrëjų, Japoniją turètų pakeisti Indija. Taigi šiuo atveju rezultatai dažniausiai sutampa su kitais eksportą analizuojančiais tyrimais.

Šiuo tyrimu identifikuotas optimalus pasaulio eksporto apimčių paskirstymas tarp šalių skiriasi nuo 0,3 iki 1,3 p. p., lyginant su 2015 m. statistiniais duomenimis (žr. 6-7 pav.). Galima daryti išvadą, kad $2015 \mathrm{~m}$. pasaulio eksporto apimtys buvo santykiškai optimaliai paskirstytos laikantis modeliu suformuotų metodinių prielaidų ir bendrųų matematinio modelio apribojimų.

Minimalios, vidutinès ir maksimalios pageidaujamos pasaulio eksporto apimties paskirstymo palyginimas. Identifikuojant pagrindinius skirtumus ir panašumus tarp trijų hipotetinių atvejų pastebima, kad trys dominuojančios šalys pasaulio eksporto apimties aspektu sutampa: Kinija, ES 28 ir JAV (žr. lent.). 
Lentelè. Trijų hipotetinių atvejų optimalių eksporto apimčių paskirstymo tarp pasaulio šalių palyginimas

\begin{tabular}{|l|r|r|r|}
\hline \multirow{2}{*}{ Pasaulio šalis, šalių grupé } & \multicolumn{3}{|c|}{ Atvejis } \\
\cline { 2 - 4 } & \multicolumn{1}{|c|}{ Xmin } & \multicolumn{1}{c|}{ Xvid } & \multicolumn{1}{c|}{ Xmax } \\
\hline Kinija & $\mathbf{1 6 , 2}$ & 14,0 & $\mathbf{1 7 , 8}$ \\
\hline ES 28 & 15,5 & $\mathbf{1 6 , 3}$ & 15,5 \\
\hline JAV & 10,9 & 13,4 & 12,1 \\
\hline Japonija & 6,1 & 4,9 & 6,1 \\
\hline Pietų Korëja & 3,9 & 3,9 & 4,1 \\
\hline Kanada & 3,2 & 3,5 & 3,2 \\
\hline Rusija & 2,7 & 3,8 & 2,7 \\
\hline Singapūras & 2,7 & 2,7 & 2,7 \\
\hline Meksika & 2,6 & 2,7 & 3,0 \\
\hline Indija & 2,1 & 2,1 & 2,1 \\
\hline Brazilija & 1,5 & 1,5 & 1,9 \\
\hline
\end{tabular}

Pastaba. Šalies eksporto apimtis pateikiama procentais. Xmin - 2011-2015 m. bendro pasaulio eksporto minimali reikšmè (procentais); Xvid - 2011-2015 m. bendro pasaulio eksporto vidutinė reikšmè (procentais); Xmax - 2011$2015 \mathrm{~m}$. bendro pasaulio eksporto maksimali reikšmè (procentais).

Kita vertus, pageidaujant minimalios ir maksimalios bendros pasaulio eksporto apimties, pasikeičia pagrindinis eksportuotojas (apimties atžvilgiu) iš ES 28 i Kiniją. Analogiška tendencija pastebima ir lyginant faktinius pasaulio eksporto duomenis 2013-2015 m. laikotarpiu (žr. 8 pav.).

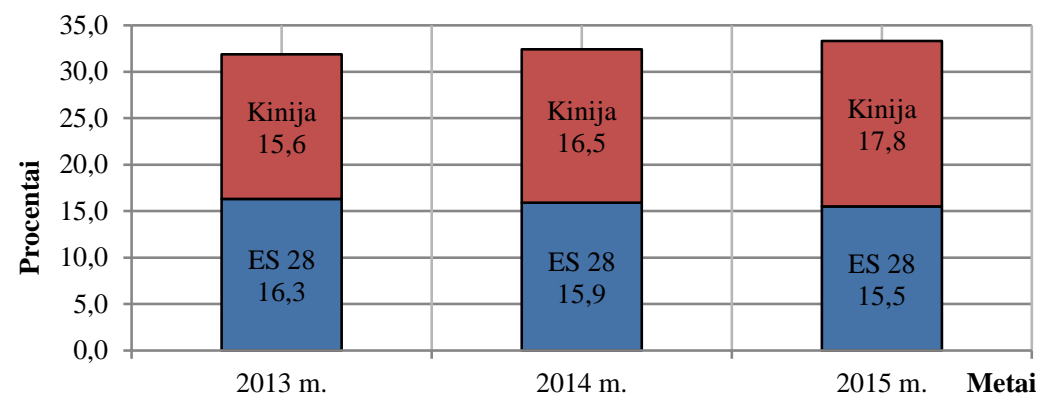

Pastaba. Paveikslas sudarytas autorès, remiantis Eurostat (2017) duomenimis. Eksportas pateikiamas procentais nuo bendros pasaulio eksporto apimties.

8 pav. ES 28 ir Kinijos eksporto dinamika 2013-2015 m.

Šią tendenciją pastebi ir akcentuoja ir V. Tauraitè (2017), tirdama 2002-2014 m. pasaulio eksportą ir atlikdama 2015 m. pasaulio eksporto prognozę. Remiantis W. Chan-Yuan'io ir kt. (2013), tokio pobūdžio Kinijos eksporto augimo potencialas ir vykdoma atvirosios rinkos politika gali būti interpretuojama dvejopai: 1) Kinijos eksporto potencialas gali būti identifikuotas kaip grèsmè kitoms šalims; 2) Kinijos teikiama produkcija gali užtikrinti platesnes viduriniosios klasès vartojimo galimybes. Mokslinėje literatūroje taip pat nagrinèjamos ir ES eksporto apimčių kitimo tendencijų priežastys. Pavyzdžiui, Makedonijos informacinio centro (Macedonian Information Centre, 2016) parengtame straipsnyje nurodoma, kad ES ir JAV eksporto svarba galimai mažèja dèl to, kad ES ir JAV tampa mažiau atviros tarptautinei prekybai.

Tarp santykiškai mažiausių eksportuotojų dviem hipotetiniais atvejais (kai pageidaujama minimali ir vidutinè pasaulio eksporto apimtis) yra Brazilija, Indija ir Meksika, t. y. besivystančios 
šalys (identifikuotos, remiantis Jungtinių Tautų Generaline Asamblëja, 2015; žr. lent.). Antruoju atveju, kai pageidaujama vidutiné pasaulio eksporto apimtis, tarp mažiausių eksportuotojų dar patenka ir Singapūras. Kita vertus, Brazilija, Indija, Singapūras ir Rusija yra mažiausios eksportuotojos, kai pageidaujama maksimali pasaulio eksporto apimtis. Remiantis statistiniais ir eksporto paskirstymo duomenimis pastebima, kad Rusijos eksporto apimtys santykiškai mažeja, lyginant 2013 m. ir 2015 m. (žr. 5, 7 pav.). Manytina, kad tam įtakos gali turèti nestabili politinè, ekonominè situacija Rusijoje bei Rusijai taikomi apribojimai kitų šalių atžvilgiu. Taigi santykiškai didžiausios eksportuotojos (Kinija, ES 28, JAV) visais trim atvejais sutampa, o tarp mažiausių eksportuotojų galima išskirti Braziliją ir Indiją.

Apibendrinant empirinio tyrimo rezultatus galima teigti, kad priklausomai nuo pasirinktos strategijos bendro pasaulio eksporto (minimalaus, vidutinio, maksimalaus) atžvilgiu, galima identifikuoti optimalų pasaulio eksporto paskirstymą tarp šalių.

\section{IŠVADOS IR PERSPEKTYVOS}

Empirinio tyrimo metu buvo taikomi trys pagrindiniai metodai: atvejo, lyginamosios analizès ir matematinio modeliavimo, naudojant tiesini programavimą. Straipsnyje taip pat pateikiami tyrimo ribotumai ir privalumai.

Išsiaiškinta, kad visais trim hipotetiniais atvejais išlieka šios eksporto apimties aspektu dominuojančios šalys: Kinija, ES 28, JAV. Santykiškai mažiausios pasaulio eksporto apimtys tenka Brazilijai ir Indijai. Nustatyta, kad, esant minimaliam pageidaujamam pasaulio eksporto dydžiui $(67,4 \%)$, egzistuoja toks optimalus eksporto paskirstymas tarp pasaulio šalių: Kinijos - 16,2\%, ES $28-15,5 \%$, JAV - 10,9\%, Japonijos - 6,1\%, Pietų Korejos - 3,9\%, Kanados - 3,2\%, Rusijos 2,7\%, Singapūro $-2,7 \%$, Meksikos $-2,6 \%$, Indijos $-2,1 \%$, Brazilijos - 1,5\%. Pageidaujant vidutinio pasaulio eksporto dydžio (68,8 \%), nustatytas toks optimalus eksporto paskirstymas: ES 28 - 16,3\%, Kinijos - 14,0\%, JAV - 13,4\%, Japonijos - 4,9\%, Pietų Korèjos - 3,9\%, Rusijos - 3,8\%, Kanados 3,5\%, Singapūro - 2,7\%, Meksikos - 2,7\%, Indijos - 2,1\%, Brazilijos - 1,5\%. Kai egzistuoja maksimalus pageidaujamas bendras pasaulio eksporto dydis (71,2\%), nustatomas tokio pobūdžio optimalus eksporto paskirstymas: Kinijos - 17,8\%, ES 28 - 15,5\%, JAV - 12,1\%, Japonijos - 6,1\%, Pietų Korèjos - 4,1\%, Kanados - 3,2\%, Meksikos - 3,0\%, Rusijos - 2,7\%, Singapūro - 2,7\%, Indijos $-2,1 \%$, Brazilijos - 1,9\%. Tyrimo pritaikymo galimybès susijusios tarptautiniu (globalios gerovès siekis tarptautinių santykių kontekste) ir nacionaliniu lygiu (šalies gerovès siekis). Tyrimas galètų būti tobulinamas tikslinant, koreguojat matematinị modelị (analizuojamo laikotarpio, šalių atžvilgiais).

Empirinio tyrimo rezultatai yra santykiškai patikimi, atsižvelgiant i tyrimo metu suformuluotas metodines prielaidas. Manytina, kad tyrimo rezultatų patikimumas būtų palyginti didesnis, jeigu empiriniam tyrimui atlikti būtų naudojama didesnè statistinių duomenų tyrimo imtis, t. y. didesnè nei penkerių metų (kaip šiuo atveju), ir į matematinị modelị ịtraukiamas ,likęs pasaulis“.

Manytina, kad optimalaus pasaulio eksporto paskirstymo modeliavimo tyrimo rezultatai ir patobulinti tyrimai analizuojama tema galètų būti aktualūs tokioms pasaulinèms organizacijoms kaip Pasaulio prekybos organizacija, Jungtinių Tautų organizacija ir kitoms. Remiantis tyrimo ir naujų tyrimų rezultatais būtų galima didinti globalią gerovę tarptautinès ekonomikos kontekste. Taigi būtų 
rekomenduojama koreguoti pasaulio eksporto paskirstymą tarp šalių, siekiant globalios gerovès ir atitinkamos bendros pasaulio eksporto apimties. Metodinių nurodymų pateikimas, susijęs su optimalaus paskirstymo realizavimu, galètų būti kito tyrimo tikslas.

\section{LITERATŪRA}

1. Burinskienè, A. (2014). Tarptautinès prekybos pokyčių analizè. Mokslas - Lietuvos ateitis. Verslas XXI amžiuje, 6 (1), 103-110.

2. Chan-Yuan, W., Gladys, S., Ran, L., Kian-Teng, K. (2013). The impact of China on the emerging world: New growth patterns in Chinese import-export activities. Engineering Economics, 24 (4), 309-319.

3. Čepinskis, J., Bendoraitienè, E. (2012). Lietuvos baldų pramonès pokyčiai ir tendencijos ekonominès krizès laikotarpiu. Taikomoji ekonomika: sisteminiai tyrimai, 6 (1), 73-84.

4. Darshini, J. S. (2017). International trade: Direction and dimension. CLEAR International Journal of Research in Commerce \& Management, 8 (1), 24-29.

5. Eurostat. (2017). Share of EU in the World Trade. Prieiga internetu: http://appsso.eurostat.ec.europa.eu/nui/submitViewTableAction.do [žiūrèta 2017-05-08].

6. Guogis, A. (2006). Socialinès politikos modeliavimas Europos integracijos procese. Viešoji politika ir administravimas, 17, 29-41.

7. Jungtinių Tautų Generalinè Asamblèja. (2015). List of developing countries. Prieiga internetu: http://www.iugg2015prague.com/list-of-developing-countries.htm [žiūrèta 2017-05-07].

8. Kee, H. L., Tang, H. (2016). Domestic value added in exports: Theory and firm evidence from China. American Economic Review, 106 (6), 1402-1436.

9. Liučvaitienè, A., Peleckis, K. (2011). Konkurencinio pranašumo formavimas globalioje rinkoje: teorinès prielaidos ir vertinimo galimybès. Scientific Conference "Contemporary Issues in Business, Management and Education' 2011", 181-194.

10. Macedonian Information Centre. (2016). The published list of world's largest export countries, Macedonia included. Macedonian Business Monthly, 16 (171), 7.

11. Mauricas, Ž. (2015). Nenatūraliai didelis natūralus nedarbo lygis Baltijos šalyse. Lietuvos ekonomikos ateities vizija, strateginiai tikslai ir valstybès misija juos igyvendinant. Jaunuju mokslininku-ekonomistu konferencijos pranešimai (pp. 178-187). Vilnius: Lietuvos mokslų akademija.

12. O'Neill, J., Wilson, D., Purushothaman, R., Stupnytska, A. (2005). How solid are the BRICs? Global Economics Paper, 134.

13. Radziukynas, V., Nemura, A. (2007). Elektros energetikos sistemos su vejo elektrinèmis matematinis modeliavimas. Energetika, 53 (3), 1-9.

14. Sergeev, I., Ponomarenko, T. (2013). Russian export of raw materials and balance of economic interests. Regional Formation \& Development Studies, 124-131.

15. Stonkienè, L. (2013). Biocheminių reakcijų matematinis modeliavimas. Moksline ataskaita MII-DS-09P13-15. Vilnius: Vilniaus universitetas. 
16. Suri, F. K., Banerji, A. (2016). A study of disaggregated R\&D expenditure on Indian pharmaceutical exports. Journal of Developing Areas, 50 (3), 167-190.

17. Tauraitè, V. (2017). Pasaulio eksporto dinaminè analizè ir prognozavimas. Laisvalaikio tyrimai, 1 (9), 112.

18. Wilson, D., Purushothaman, R. (2003). Dreaming with BRICs. The path to 2050. Global Economics Paper, 99.

\title{
THE MODELLING OF ALLOCATION OF THE OPTIMAL WORLD EXPORT
}

\author{
Viktorija Tauraitė
}

Vytautas Magnus University, Kaunas, Lithuania

\begin{abstract}
Relevance of the research. Economic, financial, commercial and other relations are becoming faster in the global world. Business, trade relations with foreign investors, the optimal implementation of international relations in micro (company) and macro (country) level are important for producers and entrepreneurs. So it is relevant to carry out the scientific research in order to find out the optimal allocation of the world export according to volume of desired overall world export by using the mathematical modelling. Although the method of mathematical modelling is used in scientific research (e. g. Stonkienè, 2013; Radziukynas, Nemura, 2007.), no study was found where mathematical modelling would be used by the linear programming method and identifying the optimal export allocation, taking into account the conditions. So, this article complements a variety of research.
\end{abstract}

The problem of the research: what is the optimal allocation of the world export between 11 countries when the volume of desired overall world export is minimum, medium or maximum?

The object of the research is the allocation of the world export.

The aim of the research is to identify the he optimal allocation of the world export between 11 countries (EU 28, Russia, Canada, the United States, Mexico, Brazil, China (except Hong Kong), Japan, South Korea, India, and Singapore) in 3 cases when the volume of desired overall world export is: 1) minimum; 2) medium; 3) maximum.

\section{The tasks of the research:}

1. To present the methodology of the research.

2. To identify the he optimal allocation of the world export between 11 countries in 3 cases according to the volume of desired overall world export.

3. To summarize the main points of the allocation of the optimal world export and to submit recommendations.

The research was carried out by using methods of case, comparative analysis and mathematical modelling applying the linear programming method. Eurostat statistical data of 2011-2015 were used for the mathematical modelling.

Outcomes and conclusions. It was found out that EU 28, China and the United States are the same dominant countries in all three cases by the aspect of the world export volume. Moreover, the least volume of the world export is in India and Brazil. On the other hand, the differences between dominant countries which should have the biggest part of world export were found. China should have the biggest part of world export 
when the volume of desired overall world export is minimum and maximum. EU 28 should have the biggest part of world export when the volume of desired overall world export is medium.

Keywords: international trade, export, mathematical modelling.

\title{
МОДЕЛИРОВАНИЕ РАСПРЕДЕЛЕНИЯ ОПТИМАЛЬНОГО МИРОВОГО ЭКСПОРТА
}

\author{
Виктория Таурайте \\ Университет Витаутаса Великого, Каунас, Литва
}

\section{PЕЗЮМЕ}

В глобальном мире экономические, финансовые отношения, отношения торговли и другие становятся всё быстрее. Производителям, бизнесменам становится выжными отношения бизнеса, продаж с зарубежными инвесторами и выполнение эффективных, оптимальных междунородных отношений на микро- и макро- уровне. Поэтому выполнение моделирования распределения оптимального мирового экспорта становится актуальным, принимая во внимание предпочтительный объём общего мирового экспорта. Хоть метод математического моделирования используется в исследованиях учёных (напр., Стонкене, 2013; Радзюкигас, Немура, 2017 и др.), но не удалось найти исследования, в которых бы использовался метод математического моделирования, применяя метод линейного программирования и определяя оптимальное распределение экспорта, принимая во внимание определённые условия. Поэтому, это исследование проводится стремясь пополнить разнообразие научных исследований.

Проблема исследования - каким является распределение оптимального экспорта между 11 стран мира, групп стран, когда желаемый общий мировой экспорт является минимальным, средним или максимальным.

Объект исследования - распределение мирового экспорта.

Цель исследования - определить оптимальное распределение мирового экспорта между 11 стран мира или групп стран (ЕС28, России, Канады, Соединённых Штатов Америки, Мексики, Бразилии, Китая (кроме Гонконга), Японии, Южной Кореи, Индии, Сингапура) по трём разным случаям, когда желаемый общий мировой экспорт является: 1) минимальным, 2) средним, 3) максимальным.

\section{Задачи исследования:}

1. Представить методику исследования.

2. Определить оптимальное распределение мирового экспорта между 11 стран мира, групп стран по трём случаям, принимая во внимание желаемый общий размер мирового экспорта.

3. Обобщить результаты оптимального распределения мирового экспорта и предоставить рекомендации. 
Исследование проводится с использованием ситуационно-сравнительных методов анализа, а математическому моделированию применяется метод линейного программирования. Математическому моделированию исспользуются 2011-2015 г. Eurostat статистические данные.

Результаты и выводы. Выяснено, что три доминирующие страны, во всех случаях в отношении объёма мирового экспорта сходятся: ЕС28, Китай и США, а самые меньшие объёмы экспорта приходятся в Индии и Бразилии.

С другой стороны, установлены различия между страной, которой достаются наибольшие объёмы экспорта: Китаю - когда желаем минимальный и максимальный объём мирового экспорта; ЕС28 - когда желаем средний объём мирового экспорта.

Ключевые слова: международная торговля, экспорт, математическое моделирование. 